\title{
CHILDREN IN THE STREETS OF BRAZIL: Drug Use, Crime, Violence, and HIV Risks
}

\author{
James A. Inciardi and Hilary L. Surratt
}

Substance Use and Misuse, 1997

\begin{abstract}
The presence of vast numbers of unsupervised and unprotected children is a phenomenon that is common throughout Latin America, and in few places are the street children more visible, and reviled, than in Brazil. Estimates of their numbers in Brazil have ranged from 7 to 17 million, but more informed assessments suggest that between 7 and 8 million children, ages 5 to 18, live and/or work on the streets of urban Brazil. Accounts of drug abuse among street youths in Brazil are commonplace. Numerous scientific studies and media stories have reported the widespread use of inhalants, marijuana and cocaine, and Valium among street children. Also common is the use of coca paste and Rohypnol. Risk of exposure to HIV is rapidly becoming an area of concern because of the large number of street youths engaging in unprotected sexual acts, both renumerated and non-renumerated. Moreover, Brazil's street children are targets of fear. Because of their drug use, predatory crimes, and general unacceptability on urban thoroughfares, they are frequently the targets of local vigilante groups, drug gangs, and police "death squads." Although there have been many proposals and programs for addressing the problems of Brazilian street youth, it would appear that only minimal headway has been achieved.

The United Nations Center for Human Rights has estimated that by the year 2000 half of the world's population will be under 25 years of age and located in cities, and that significant numbers will be living in poverty (UNICEF, 1996a). The United Nations also estimated that by the end of this century there will be almost 250 million more urban children in the 5-to-19 year old age cohort then there were in the mid-1980s; that more than $90 \%$ of these youths will be living in developing nations; and that by the year 2020 there will be some 100 million indigent urban minors in Latin America alone. It is likely, furthermore, that many of these children will be living in the streets (UNICEF, 1996b).
\end{abstract}


The use of the street as a place to live and/or work is not unknown to most industrial economies, but the presence of vast numbers of unsupervised and unprotected children is a phenomenon that is visible only in developing nations, and particularly in Latin America (Rizzini and Lusk, 1995; Lusk, 1989). Estimates of the number of street children throughout Central and South America vary widely, but the United Nations Children's Fund figure of 40 million is the most generally accepted (UNICEF, 1996b). Many of these youths are exploited and abused, and because of their pariah status in the eyes of the public they are referred to with a variety of disapproving appellations -- gamines (urchins) and chinches in Colombia, pajaros fruteros in Peru, and marginais (nonessentials or criminals), pivetes (little farts), and abandonados (children who have nowhere else to go) in Brazil. And in few places are the street children more visible, and reviled, than in Brazil.

\section{The Demographics of Inequality in Brazil}

Brazil is often referred to as the land of perpetual promise. It is also a land of great diversity. It is the rain forests of Amazonia and the factories of São Paulo; it is the turquoise beaches of Bahia and the swamps of the Pantanal; and it is Carnaval in Rio de Janeiro and the gauchos of Rio Grande do Sul. And Brazil is Copacabana and Corcovado, the samba and capoeira, and soccer, feijoada, Pelé, cachaça, and world beat. But at the same time, Brazil ranks near the bottom of the hemisphere in its standard of living, health status, and social indicators. Some 55 million people, 33\% of Brazil's total population, are under age 16 and 35 million children are living in families earning well under the minimum wage (UNICEF, 1996b). Almost half of all Brazilian families live below the poverty line (88\% of the minimum wage), and almost a third are below the indigency line (53\% of the minimum wage). ${ }^{(1)}$ More than $18 \%$ of Brazil's population is illiterate, and 35\% of children between ages 7 and 15 are not enrolled in school. In addition, with the exception of Haiti and Guatemala, malnutrition is more prevalent in Brazil than in any other Latin American or Caribbean nation (UNICEF, 1996b). According to official government statistics, 1,000 children die from hunger and malnutrition each day in Brazil. Moreover, Brazil's infant mortality rate in 1993 was 52 per 1,000 live births, one of the highest in Latin America and exceeded only by Peru (88) and Bolivia (98). In the poorest regions of the country and in impoverished areas near industrial centers, $10 \%$ of the children are expected to die before they reach 5 years of age (Martins, 1993).

These discouraging numbers documenting the destitution of millions of Brazilians become even more bewildering when one considers that Brazil has a higher per capita GNP -$\$ 2,770$-- than any other Latin American country (except Uruguay). Brazil is a relatively wealthy country and possesses the tenth largest economy in the world, but the distribution of resources within its population is highly skewed. In fact, in 1996 the World Bank reported that for the second year in a row Brazil had the most lopsided income distribution in the world (Latinamerica Press, 1996). For example, the wealthiest $20 \%$ of the population earned $65 \%$ of the country's total income, leaving only $12 \%$ for the poorest half. When Brazil is compared with other countries, the problem of inequity becomes even more obvious. The wealthiest $10 \%$ of the population earned 30 times more than the average income of the most impoverished $40 \%$-- a proportion that is ten-to-one in Argentina, nine-to-one in the United States, and only five-to-one in most European countries (Latinamerica Press, 1996; Michaels, 1993).

Moreover, there is a staggering amount of land concentration in Brazil, with $43 \%$ of the total land area owned by $1 \%$ of the population (Raphael and Berkman, 1992). 
The striking economic disparity that exists between different segments of Brazilian society has its roots in regional inequalities and racial discrimination. During Brazil's "Economic Miracle" of the 1970s, government funds and foreign loans flowed into the industries of the south, resulting in improved standards of living and employment opportunities in that area of the country. In the agricultural northern regions, however, the poverty rate increased $9 \%$ over this same time period (Raphael and Berkman, 1992). Further, the aim of the Brazilian government to achieve "economic growth at all costs" led to a decrease in spending for health care, social programs, and educational initiatives. As a result, the proportion of malnourished children under age 5 increased from $13.7 \%$ in the late 1970 s to $30.7 \%$ by the end of the 1980 s.

With respect to economic disparity and racial inequality, Brazil is thought to have the largest black population of any country outside of Africa, with about 70 million people, or 46\% of the total population being Afro-Brazilians (International Child Resource Institute, 1994). Blacks in Brazil are typically overrepresented in the lowest income levels and represent the majority of the under-employed (International Child Resource Institute, 1994). Several studies have documented that incomes of white Brazilians are, on average, twice that of black Brazilians (International Child Resource Institute, 1994; Raphael and Berkman, 1992; Wood and Magno de Carvalho, 1988). In addition, a World Bank study found that almost 30\% of Afro-Brazilian children live in households with incomes at the lowest wage levels (Tilak, 1989).

An important consequence of regional and racial economic inequalities in Brazil has been a massive influx of migrants from rural to urban areas. Over the past 20 years, cities throughout Brazil have absorbed over 29 million migrants seeking employment and a better life for themselves and their families. Others were evicted from their land by mining projects or cattle raising (International Child Resource Institute, 1994). This influx of migrants created a seemingly inexhaustible pool of unskilled laborers in Brazil's large cities. Moreover, the infrastructure of these urban areas has increasingly been unable to expand to meet the demands for health care, education, and employment. As a result, slum dwellings, unemployment, hunger, and violence have risen dramatically. Currently, 75\% of all Brazilians live in cities, and among them are 52 million boys and girls under age 19 (Eisenstein, 1992).

The Southeastern region of Brazil, where São Paulo and Rio de Janeiro are situated, is the most heavily populated section of the country. It is estimated that in metropolitan Rio de Janeiro and São Paulo alone there are several million children living in extreme poverty. And it is this destitution which drives children to the streets in an attempt to survive.

\section{Meninos de Rua (Street Kids) and the New Face of Child Labor}

Throughout Latin America, meninos de rua (in Brazilian Portuguese) or niños de la calle (in Spanish) represent the new face of child labor -- youths working in the urban informal sector. Their occupations range from shining shoes, selling cigarettes, flowers, newspapers or chewing gum, to hauling garbage, drug trafficking, petty theft, street robberies, and prostitution.

The existence of street children in the large metropolitan areas of Brazil is not particularly new. The international media began to document the condition of large numbers of Brazilian 
street children as early as the 1970s. Despite the significant media attention over the past 15 to 20 years, however, much remains unknown about their daily lives and activities. In fact, even approximating the actual size of the population of street children has proven difficult. Estimates of their numbers in Brazil have ranged from 7 to 17 million, but more informed assessments suggest that between 7 and 8 million children, ages 5 to 18, live and/or work on the streets of urban Brazil. While the vast majority of street children are boys, Brazilian government estimates put the number of street girls at approximately 800,000, with almost two-thirds of them working as prostitutes in various parts of the country (Barker, 1992).

Part of the problem in estimating the number of street children lies in the distinction between what are known as "children on the street" and "children of the street" (Campos et al., 1994b; Lusk, 1989). Children on the street work in informal sector occupations in order to supplement the family income, but return home at night to sleep. These children typically reside in households headed by impoverished, single women and spend most of the day and night in the street selling candy or gum, guarding cars, shining shoes, or carrying groceries.

By contrast, children of the street have oftentimes completely severed ties with their families. They seemingly choose to leave homes where hunger, neglect, and exploitation are commonplace, making life on the street preferable. A very small number of children actually live full-time in the streets, often engaging in illegal activities in order to survive. In fact, children of the street are more typically associated with theft, drug sales, petty theft, prostitution, and gang activity. Younger children often begin their careers on the street by begging, but rely increasingly on crime to support themselves as they age and become less successful at panhandling. Young street girls commonly use prostitution as a way of supporting themselves.

As indicated in Table 1, the United Nations Children's Fund estimates that the number of "working children" (children on the street) and "street children" (children of the street) throughout Latin America total as many as 40 million.

Table 1. "Working Children" and "Street Children" in Selected Latin American and Caribbean Nations

\begin{tabular}{|l|c|c|}
\hline Country & Working Children & Street Children \\
\hline Argentina & 2.35 million & $20,000^{*}$ \\
\hline Bolivia & 72,000 & 200 \\
\hline Brazil & 7.4 million & 8 million** \\
\hline Costa Rica & 53,000 & 5,300 \\
\hline Ecuador & 1 million & 4,000 \\
\hline El Salvador & 231,000 & 10,000 \\
\hline Guatemala & 1.62 million & $1,000^{* * *}$ \\
\hline Haiti & 120,000 & 10,000 \\
\hline Honduras & 275,000 & 800 \\
\hline Mexico & 10 million & 250,000 \\
\hline
\end{tabular}

*Includes Buenos Aires only. 
**May include children working, but not living, on the street.

***Includes Guatemala City only.

Source: UNICEF, Regional Office for Latin America, Bogota.

As the number of street children and their related criminal activity continue to grow, so does public opposition to their presence. Over the past twenty or so years, public opinion has shifted dramatically. Youngsters who were once looked upon as deserving of compassion and sympathy are now viewed at best as a nuisance, and at worst as a danger to public safety -future criminals who ought to be locked up. Although popular views characterize these children as delinquents and thieves, perhaps Nancy Scheper-Hughes most accurately described street youths in modern Brazil as simply "poor children in the wrong place" (Scheper-Hughes and Hoffman, 1994). Perhaps it was this sentiment that enabled the Brazilian National Congress was to pass the Child and Adolescent Act in 1990. This statute was designed to reform the legal status of children in Brazil and to create councils that would act as children's rights advocates, with an eye toward integrating impoverished children into the larger society. However, negative attitudes toward street children by the Brazilian people prevail and public resistance to such reforms continues to frustrate attempts to implement the statute.

\section{The Children of the Favelas}

Important to understanding the presence of large numbers of street children in Latin America in general, and in Brazil in particular, is a comprehension of the nature of primate cities and what life is like in the thousands of primate city shantytowns.

Most developing countries contain one or more "primate cities," urban areas that grow in population and influence far beyond the other cities in the region or nation. In many Latin American countries, and in other developing nations as well, the largest cities may have several times the combined populations of the next two or three urban areas and may also have a significant share of the national population. Mexico City's population of 16 million, for example, accounts for $20 \%$ of the nation's population, while other cities are considerably smaller: Guadalajara (1.6 million), Monterrey (1.1 million), and Puebla de Zaragoza (1.1 million). Similarly, the populations of Brazil's two largest cities -- São Paulo and Rio de Janeiro -- combine to account for some $16 \%$ of the national population.

Primate cities typically are located on the coast or in other areas close to transportation routes, since many were political and economic centers when under colonial rule. The orientation of such cities had been toward supplying the developed nations with raw materials and other goods, rather than toward the urban areas and hinterlands of their own country.

Among the greatest difficulties experienced by these cities in Latin America are those of stimulating industrialization and providing employment. People who move into these urban locales do so, not because of the employment opportunities the cities provide, but because the living conditions in rural areas seem so much worse. Previous research has suggested that rural populations have been "forced" to relocate because of increasing agricultural density and the inability of the land to support its people (Firebaugh, 1979). Rural-urban migrants believe that the cities offer a better life and at least the hope for employment. Some do find work in small 
enterprises, but the lack of sophisticated technology and industrial production methods does not provide for the large pool of unskilled labor that characterized the Western industrial revolution. As a result, the unemployment rates in the cities of many developing nations exceed $25 \%$ of the labor force.

Common features of the primate city landscape are the sections comprised of shanties, shacks, and makeshift huts inhabited by those who have no other shelter. Known as barriadas in Peru, ranchos in Venezuela, villas miserias in Argentina, or favelas in Brazil, these squatter settlements have been estimated to house as much as one-third of the urban population (Butterworth and Chance, 1981:151-157). Mexico City has some 4 million squatters, Calcutta has 2 million, and Rio de Janeiro has over 1 million.

Favelas have been a feature of urban Brazil for generations (Freyre, 1986). Favela in Brazilian Portuguese means "slum." Yet it is a particular type of slum that takes its name from Morro da Favela, a hill near Rio de Janeiro where the first one appeared in the late 1880s. In 1963, the noted journalist and biographer John Dos Passos commented:

In Rio -- this was in 1948 -- there were said to be three hundred thousand people living in favelas. Today there are nearer a million. You come on favelas in the most unexpected places. In Copacabana a few minutes walk from the hotels and the splendid white apartment houses and the wellkept magnificent beaches you find a whole hillside of favelas overlooking the lake and the Jockey Club. In the center of Rio a few steps from the Avenida Rio Branco on the hill back of one of the most fashionable churches you come suddenly into a tropical jungletown (Dos Passos, 1963:31).

Similarly, in 1966 travel writer John Gunther described Rio's favelas as "vertical" in character -- since they were situated on hillsides:

This came about partly because much of the land in Rio is too steep for normal building purposes and, when urbanization began on a serious scale, speculators let the hills alone. So the squatters swarmed to the cliffs, scraped off plots from jungle shrubbery, and built their miserable huts out of tin cans, hunks of stone, and cardboard, on the sharpest slopes. The irony is that they now have the best views in the city. But there are no amenities whatever, not even water or a postal service. Filth and flies are everywhere. Dogs howl, and children drip with slime (Gunther, 1966:72).

The favelas situated on the hillsides of Rio de Janeiro are the best known and most notorious. They began to appear at the end of the nineteenth century, and spread rapidly after 1930 as shelters for newly-arriving migrants (Burns, 1980:569). Fleeing regions hard-hit by drought and unemployment, rural Brazilians thronged to cidade maravilhosa, the "marvelous city" of Rio de Janeiro, lured by its illusionary riches. There has been a steady stream even 
since, and at the close of the 1980s it was estimated that some 1,500 "favelados" were arriving each day (Archambault, 1989).

Little has changed since Dos Passos and Gunther made their observations three decades ago. In the great majority of the favelas, migrants from all over Brazil have recreated a semirural way of life, in neighborhoods with names which often reflect a bittersweet Brazilian humor -- Morro da Esperança (Hill of Hope), Chácara do Céu (Sky Gardens), and Nova Brasília (New Brasília). In Rio de Janeiro, the favelas have been estimated by Brazil's Municipal Planning Institute to number 545 and house more than 1 million persons -- some 14\% of the city's population (Loveman, 1991). Clustered on the hill and mountainsides that overlook Rio's fashionable beaches and elegant shopping and high-rise centers, the favelas are slums in which only a small portion of households have electricity, running water, or sewage facilities. Juramento, for example, like most other favelas, is a self-contained realm of the very poor, with 30,000 residences and a dozen or so entry points (Rambali, 1993). There is no glass in the windows of the shacks, no electricity or water other than what can be tapped from city lines, and when it rains the gutters run with mud and refuse. The hill is riddled with alleys and passageways, but there are no official street names, and no mail service or telephone lines.

In the absence of public medical facilities and unemployment benefits for the more than $50 \%$ of out-of-work favelados, disease and social problems multiply. There is prostitution and drug use, and a key feature of most favelas is cocaine trafficking (Guillermoprieto, 1990). Within such a setting, it is no wonder that so many children retreat from the favelas to the streets -- in Rio de Janeiro, São Paulo, Belo Horizonte, Porto Alegre, Santos, Fortaleza, Recife, and other Brazilian cities. And in Rio, a city where street children have received considerable media attention, they withdraw from the favelas to Copacabana, Ipanema, Lapa, Botafogo, Tijuca, and other sections of the "asphalt city." The total number of street youths in Rio de Janeiro has been the topic of considerable media conjecture and exaggeration, with some estimates as high 1 million. Local public health officials put the number of "children of the street" at 2,000 - 3,000 (Facts on File, 1996), which still is a major social problem.

\section{Drug Use Among Street Youths}

Anecdotal accounts of drug abuse among street youths in Brazil are commonplace. Numerous media stories have reported the widespread use of inhalants (such as glue, gasoline, lighter fluid, bim -- a mixture of ethyl alcohol, sugar and benzene), marijuana and cocaine, and Valium among street children in Rio de Janeiro (Brookes, 1991; Larmer, 1992). Also common is the use of coca paste and Rohypnol.

Common not only in the drug-using communities of Brazil, but also in those of Colombia, Bolivia, Venezuela, Ecuador, and Peru, is the use of coca paste, known to most South Americans as basuco, susuko, pasta basica de cocaina, pasta de coca, or just simply pasta (Jeri, 1984). Perhaps best known as "basuco," coca paste is one of the intermediate products in the processing of the coca leaf into cocaine. It is typically smoked straight, or in cigarettes mixed with either tobacco or marijuana.

The smoking of coca paste became popular in South America beginning in the early 1970s. It was readily available, inexpensive, had a high cocaine content, and was absorbed quickly. As the phenomenon was studied, however, it was quickly realized that paste smoking 
was far more serious than any other form of cocaine use. In addition to cocaine, paste contains traces of all the chemicals used to initially process the coca leaves--kerosene, sulfuric acid, methanol, benzoic acid, and the oxidized products of these solvents, plus any number of other alkaloids that are present in the coca leaf (Almeida, 1978).

When the smoking of paste was first noted in South America it seemed to be restricted to the coca processing regions of Bolivia, Colombia, Ecuador, and Peru, appealing primarily to street children and low-income groups due to its cheap price when compared with that of refined cocaine (Jeri, Sanchez, and del Pozo, 1976). By the early 1980s, however, it had spread to other South American nations, including Brazil, to numerous segments of the social strata, and throughout the decade paste smoking further expanded to become a major drug problem for much of South America. ${ }^{(2)}$ Among the Rio's street youth of the 1990s, the smoking of pasta de coca remains an enduring problem.

By contrast, Rohypnol is a legal drug in Brazil, readily available in pharmacies in many parts of the world. Also known by its generic name flunitrazepam, Rohypnol is a benzodiazepine drug having anticonvulsant and sedative effects, slowing psychomotor performance, and inducing muscle relaxation and sleep. It is used for the short-term treatment of insomnia. However, its use can lead to the development of physical and psychic dependence, with the risk of addiction increasing with dose and duration of use (Saum and Inciardi, 1997).

Rohypnol is similar to Valium, but ten times as potent. It was first introduced in the 1970s, and is legally available throughout Europe and Latin America. Since the 1980s it has been used to counter some the negative side effects of cocaine abuse. In addition, combining Rohypnol with alcohol, cocaine, or marijuana reportedly produces a fast hit followed by a mellow state which lasts for several hours.

Many street youths in Rio de Janeiro see their use of inhalants, coca paste, marijuana, Rohypnol and other drugs as an escape -- a way to dull their hunger and facilitate acts of prostitution and other crimes (Barker, 1992; Vasconcelos, 1990). And as one young female prostitute observed:

When I was prostituting at the boarding house, my father would go there and want to pay me to have sex with him. I would never do it and every time he would leave, I would smoke a lot of marijuana to try and forget the things that he would say.

Indeed, it has been observed that drug use by street children is a nearly universal phenomenon because these youths are confronted with the harsh realities of street life on a daily basis (Lusk, 1989). Given that drug abuse among youths has emerged as a concomitant of life on the streets, the paucity of scientific studies which have examined this and other related topics among street children in Brazil is troubling.

Although previous research on drug use among street children is limited, existing studies have found rates of use to be high. A survey among 119 street children in São Paulo, for example, classified $45 \%$ as heavy drug users, indicating the use of up to three drugs a day (Dimenstein, 1991). In a study of street youths in Belo Horizonte, a city of 2 million people some $452 \mathrm{~km}$ northeast of Rio de Janeiro, 84\% of the children living full-time in the street had histories of illegal drug use, $10.6 \%$ reported injection drug use, and $83.5 \%$ were sexually 
active (Campos et al., 1994b). Additionally, in an earlier study involving this same sample, 82.6\% reported having had sex while under the influence of drugs and/or alcohol. In comparison, of the working but "home-based" children interviewed, only $25 \%$ had histories of illegal drug use and none reported the use of injection drugs (Campos et al., 1992). A similar study supported these findings by reporting higher rates of drug use among "street-based" youth than "home-based" youth, $76.9 \%$ vs. $29.1 \%$, and earlier onset of drug use -- 9.8 years versus 11.2 years (Pinto et al., 1992). Moreover, a 1992 study of 98 street children in Rio de Janeiro found that $90.8 \%$ believed drug abuse to be a problem in the community and $38.8 \%$ stated that drug use was a personal problem for them (Eisenstein and de Aquino, 1992). The most commonly used drugs among these children were glue (13.3\%), marijuana (13.3\%), alcohol/tobacco (12.2\%), and cocaine (11.2\%). Nearly 70\% of this sample refused to respond to questions about injection drug use.

The most in depth study of drug use among street youths was conducted in 1992 by the Guidance Center on Drugs and the Treatment of Drug Addicts of the University of Brasília (de Paula, 1992). The research sampled 150 males ages 10 to 17 in Ceilândia, one of Brasília's satellite towns, and examined three groups of street children -- youths with no school or family ties, youths receiving assistance from social welfare institutions (typically delinquents), and youths enrolled in local schools. The data indicated that a full $100 \%$ of the street youths interviewed used drugs. Solvents and inhalants, typically cobbler's glue, were the most commonly used. "Frequent use," defined as daily or several times a week, was found among $88 \%$ of the entire sample, and among $72 \%$ of those in social welfare institutions. In addition, $32 \%$ of the youths reported the use of marijuana and/or cocaine. The latter drugs are purchased from local dealers, while the inhalants can be obtained legally in in a variety of places.

The fact that solvents and inhalants are the drugs most frequently used by street youths was not an unanticipated finding of the Brasília study, because prior studies have found these drugs to be common among other youth populations as well. In a study of 1,836 São Paulo students (ages 9 to 18 years) from low socioeconomic backgrounds, 24\% reported lifetime use of inhalants and $4.9 \%$ reported use in the last 30 days (Carlini-Cotrim and Carlini, 1988). Moreover, in a 10 -city survey of 16,300 Brazilian public school students $26.2 \%$ reported lifetime use of psychotropic drugs -- typically solvents and inhalants (Carlin and CarliniCotrim, 1993).

\section{Sex and HIV Risks}

Regardless of whether they reported any use of illegal drugs, street children have frequently related engaging in risky sexual behaviors. Street studies in Rio de Janeiro have concluded that a "second shift" of children are visible on the streets at night. Unlike their daytime counterparts, these "second shift" children tend to be older and are more likely to be female. Among them, prostitution is frequent by both boys and girls (Lusk, 1989). A 1992 study of 62 children found that $48.4 \%$ had engaged in sex, $60 \%$ with adult men, $16.6 \%$ reported sex for money, but only 33.3\% reported any use of condoms (Campos et al., 1994a).

In addition to solicitation for prostitution, many street children have reported incidents of rape. Scheper-Hughes and Hoffman (1994) observed that street girls and boys are frequently raped by police and others. Surprisingly, however, the perpetrators are not always male. Vasconcelos (1990) noted that older street girls will sometimes force younger girls to have sex 
with them, thereby continuing the cycle of violence of which they too have been victims. Of the 98 street children interviewed by Eisenstein and de Aquino (1992), 53.1\% were sexually active and $44.9 \%$ reported being forced to have sex. Similarly, a survey of 52 HIV seropositive street youths under age 16 in Rio de Janeiro found that 28\% had had anal intercourse, presumably forced. Of those ages 7 to 12, 63\% had had anal intercourse and 57\% had been forced to have anal intercourse by older street children (van Buuren and Bezerra, 1992).

Although this type of sexual violence appears to be common, it is not always necessary. Many street children use sex as a way to gain affection and attention (Scheper-Hughes and Hoffman, 1994). For this reason, younger girls at times voluntarily seek sexual contact with older girls (Vasconcelos, 1990). Sexual activity among boys is also relatively common. Some $21 \%$ of street boys interviewed in a 1991 study reported same-sex anal intercourse (Ude et al., 1991). Heterosexual anal intercourse was reported by $43 \%$ of these same respondents.

Despite high rates of sexual activity among street children, attitudes regarding condom use are for the most part negative and usage rates are low. Various studies have reported the proportion of sexually active street children having ever used condoms to be in the range of 8.2\% to 33.3\% (Campos et al., 1994a; Eisenstein and de Aquino, 1992; Raffaelli et al., 1992; Ude et al., 1991).

Risk of exposure to HIV is rapidly becoming an area of concern because of the large number of street youths engaging in unprotected sexual acts, both renumerated and nonrenumerated. On the whole, the World Health Organization reckons that there are between 50,000 and 100,000 HIV positive children and adolescents in Brazil. Going further, it has also been estimated that between 1\% and 2\% of Brazil's population of 7-8 million street children, or between 70,000 and 110,000 individuals, are HIV positive. A study in 1987-1988 at the FUNBEM Hospital in Rio de Janeiro found that among 3,389 street children, 50 (1.5\%) were HIV positive (Eisenstein, 1993). However, a more recent study conducted between May 1991 and January 1994 found that of 126 street children interviewed and tested, 94\% reported HIV risk behaviors, and 6\% were HIV seropositive (Adams et al., 1994).

\section{Violence Against Street Children}

Street children throughout Latin America are viewed by many police groups, merchants, and other citizens as undesirable, pariah populations (Thomas, 1995:88-89). In Brazil, they are targets of fear, and are seen by the upper classes and the political right-wing as being:

... a blemish on the urban landscape and a reminder that all is not well in the country. Unwanted and considered human waste, these ubiquitous tattered, mainly black children and adolescents evoke strong and contradictory emotions of fear, aversion, pity and anger in those who view their neighborhood streets, boulevards and squares as 'private places" under siege (Scheper-Hughes and Hoffman, 1994:23). 
Because of their drug use, predatory crimes, and general unacceptability on urban thoroughfares, street children have frequently been the targets of local vigilante groups, drug gangs, and police "death squads."

Perhaps most notorious have been the death squads, which initially appeared in Brazil in 1968, and principally in Rio de Janeiro, at first to avenge the terrorist murder of a well-known police officer. The death squads proliferated during the years of Brazil's military rule, which ended in 1985. As the killings spread, political and community leaders were often targeted, and the victims were easily recognized. Their hands were always tied behind their backs, their tongues cut out, and a crudely drawn skull and cross-bones were left on the corpse with the initials "E.M."--"Esquadrão de Morte"--appended.

News reports have suggested that there are many such police assassination squads in Latin America (Barker, 1992). Guatemala had its La Mano Blanco (The White Hand), Argentina its Anti-Communist Alliance, the Dominican Republic its La Banda gang, and in Brazil, Paraguay, Honduras, and El Salvador simply Esquadrão de Morte or Esquadron de Muerte--"Death Squad." All were organized, but unofficial, police vigilante organizations established with the aim not only of preserving their respective political regimes through selective political murders, but also of eliminating those viewed by the police as "undesirables"--trade unionists, drug dealers, thieves and other criminals, and not surprisingly, street children.

Many of the death squads still exist, particularly in Brazil, and street children are common victims. Because they survive, in part, through prostitution and crime, they have become the targets of retributive violence by police death squads and merchants' vigilante groups (Martins, 1992). Considered to be bad for business, store owners hire off-duty police officers or professional killers to eliminate the "disposable children." Their elimination is also seen as a mechanism of "social cleansing." There is considerable public support for the death squads as the result of perceptions that street children are dangerous criminals. Residents of the poorest communities are often the strongest supporters of violent solutions to local crime, perhaps because their neighborhoods are the least secure.

The most notorious of the death squad killings of street children occurred in 1993 in Rio de Janeiro. At 1 A.M. on July 25th, as 50 homeless youths were sleeping on the grounds of the Candelaria Cathedral in the downtown section of the city, a group of gunmen drove up and began shooting (Ellison, 1994; Dewees and Klees, 1995). Four of the youths died instantly, a fifth was shot and killed as he ran, two more were abducted, beaten, shot and dumped in the gardens of the nearby Museum of Modern Art, and an eighth died several days later, never waking from a coma. Eight others were also shot, but survived their wounds. Three members of the Military Police were arrested for the crimes, and the shootings were reportedly provoked by an occurrence earlier in the day in which some of the children had allegedly thrown stones at a military police vehicle after one youth had been detained for drug use. The incident captured headlines worldwide. A commission was established to investigate the "Candelaria massacre," but its progress was slowed when two of its members were slain in Rio de Janeiro by unidentified gunmen (Facts on File, 1996). Nevertheless, on April 30, 1996, one of the police officers -- Marcos Vinicius Borges Emmanuel, who had admitted to one of the killings - was convicted on six counts of murder, five counts of attempted murder, and several counts of grievous bodily harm, and received a sentence of 309 years (Facts on File, 1996). ${ }^{(3)}$ 
Street children are also the targets of drug gangs. Because Brazil's Protective Child Statute holds that children under 18 years of age may not be arrested unless caught in the act of committing a crime, to the drug gangs the youths' impunity makes them ideal couriers. But they are often killed because they know too much, steal too much, or get caught in the crossfire (Michaels, 1993).

The hierarchy of the favela drug trade is a vertical one, and children are recruited into the lowest level, serving primarily as lookouts. They progress to running errands for the hillside dealers, and if they are successful, they begin delivering drugs to customers. Survivors from these operations may become armed "controllers" (security guards who protect the operation and proceeds of drug transactions). Finally, there are the corporate levels of the local drug business, but few children ever last that long. Most die while they are still at the lower end of the hierarchy. When a hillside dealer is dissatisfied with a child's work, or decides that the youth is dangerous as a witness, he or she is simply killed (Raphael and Berkman, 1992). And altogether, it is estimated that as many as four to five street children are murdered each day throughout Brazil, and two each day in Rio de Janeiro alone (ICRI, 1996).

\section{Intervention Strategies}

Although there have been many proposals and programs for addressing the problems of Brazilian street youth (Eisenstein, 1993, 1994; Kirsch, 1995), it would appear that only minimal headway has been achieved. At the most general level, programs appear to be of four types: a) the correctional approach; b) the rehabilitative perspective; c) outreach strategies; and, d) the preventive outlook (Lusk, 1989).

The correctional approach views street children as a matter for juvenile justice organizations. This correctional vision seems to dominate the thinking of much of the public and criminal justice authorities. The result is that thousands of street children are housed in institutions. In Brazil, the National Foundation for Child Welfare (FUNABEM) operates twenty treatment centers and "reform" schools for abandoned and delinquent youth. Conditions in these facilities have been described as both crowded and abusive (Lusk, 1989). However, some changes appear to be underway, involving the substitution of correctional initiatives with community-based treatment alternatives.

The rehabilitative approach has been gaining momentum throughout Latin America. This perspective holds that street children are not delinquents as much as they are victims of poverty, child abuse and neglect, and untenable living conditions. Because street children are seen as having been harmed by their environments, hundreds of church and voluntary programs have been organized in their behalf. These typically provide housing, drug detoxification, education, and/or work programs. But there is a difficulty. The programs benefit only a limited number of youths, and are unable to address the needs of the millions of boys and girls who continue to call the streets their home.

Because the institutional capacities and resources of virtually all programs are limited and unable to accommodate the overwhelming majority street children, services are also provided through a variety of outreach strategies. In São Paulo, for example, the Catholic Church supports young lay workers who provide educational, counseling, and advocacy services to children in a street setting. In addition to teaching basic hygiene, literacy, and business skills, 
the general program approach is to instill self-reliance and empowerment so that children will find solutions to their problems. However, it would appear that this street educator model is overly ideological, and fails to deal with the immediate physical and safety needs of street children. Most recently, outreach strategies have been focusing on HIV prevention and risk reduction (Wiik, Filgueiras, and Castro, 1989; Siqueira et al., 1992). The effectiveness of these initiatives, however, is unclear.

The preventive approach attempts to address the fundamental and underlying problem of childhood poverty. In this regard, UNICEF is conducting educational campaigns to alert policy makers to the causes of children moving to the streets. In addition to policy advocacy, UNICEF provides technical assistance and support for promising local efforts. Those receiving UNICEF's focused attention are of two types: 1) programs which provide daytime activities, schooling, jobs, and other alternatives to street work for high risk children; and 2) efforts focusing on the prevention of family disintegration--cooperative day care centers, family planning clinics, small business services, and community kitchens (Lusk, 1989).

The most comprehensive effort on behalf of Brazilian street youth is the National Movement for Street Children (Movimento Nacional de Meninos e Meninas de Rua/MNMMR), a nationwide coalition of street children and adult educators founded in 1985 (Raphael and Berkman, 1992). MNMMR initiatives focus on shifting the management of street children away from the criminal justice system, codifying the rights of children into law, and structuring innovative approaches for providing education and training for youths directly on the streets where they live. MNMMR projects are targeting an estimated 80,000 youths, the great majority of whom work on the streets and live in nearby favelas, with the remaining actually living on the streets.

\section{Postscript}

Street children in Brazilian cities are legion. Their actual numbers are difficult to estimate, however, and have often been exaggerated. As one observer put it:

They seem to be everywhere: begging in front of restaurants, peddling cigarettes in sidewalk cafes, shining shoes outside the train station, washing clothes in public fountains. Take a morning stroll on the elegant, black-and-white mosaic sidewalk that curves along Rio's Copacabana Beach and you'll smell them; dozens sleep under the palms there, and the beach serves as a toilet (Brookes, 1991:14).

For those who work the streets during the day, returning to their favela homes at night, life is harsh and unkind. For the rest who live in the streets day and night, life is mean and unusually short. And for the great majority of Brazil's street children, it would appear that few changes are likely. Prostitution, drug use, infections, and illiteracy are common, yet there are few programs available to address the many needs of youths. 
After his election in 1991, Brazilian President Collor de Mello announced a dramatic plan to build 5,000 model schools called CIACs (Centros Integrados de Apoio à Criança/Integrated support Centers for Children) for indigent children and youth over a four-year period. They were conceived to offer indigent youths comprehensive classroom instruction and after school care, three meals a day, medical and psychological attention, shower facilities, sports and cultural activities, and a library. But by the time President Collor was removed from office on charges of fraud and embezzlement, only twenty had been built, and only few of these had actually been opened. And not surprisingly, the future of the remaining schools continues to be in doubt. In the meantime, as poverty endures, the numbers of street children slowly increase, as does their involvement in drug use, prostitution, crime, and HIV risk behaviors.

\section{REFERENCES}

ADAMS, I., MARTINS, R., CAMPOS, M., and PAIVA, J. (1994) The Ammor population. Presented at 10th International Conference on AIDS, Yokohama.

ALMEIDA, M. (1978). Contrabucion al estudio de la historia natural de la dependencia a la pasta basica de cocaina. Revista de Neuro-Psiquiatria 41:44-45.

ARCHAMBAULT, C. (1989). Rio's shaky shantytowns. IRDC Reports April:18-19.

BARKER, G. (1992). More than a minor problem. Institute of the Americas Hemisfile, vol. 3, January:6.

BROOKES, S. (1991). Life on Rio's mean streets. Insight, vol. 5, August 5:12-19.

BURNS, E. (1980). A History of Brazil. New York:Columbia University Press.

BUTTERWORTH, D., and CHANCE, J.K. (1981). Latin American Urbanization. Cambridge:Cambridge University Press.

CAMPOS, R., ANTUNES, C., JERONYMO, M., RAFFAELLI, M., PAYNE-MERRITT, A., HALSEY, N., and GRECO, D. (1992). Comparison of behavioral risks for HIV infection among sub-groups of brazilian street youth. Presented at 8th International Conference on AIDS, Amsterdam, The Netherlands.

CAMPOS, R., GRECO, M., UDE, W., MACHADO, A., RAFFAELLI, M., CAMPOS, M., and GRECO, D. (1994a). Female street youths: Social factors associated to behavioral risks for HIV infection. Presented at 10th International Conference on AIDS, Yokohama, Japan.

CAMPOS, R., RAFFAELLI, M., UDE, W., GRECO, M., RUFF, A., ROLF, J., ANTUNES, C., HALSEY, N., and GRECO, D. (1994b). Social networks and daily activities of street youth in Belo Horizonte, Brazil. Child Development 65:319-330.

CARLINI, E.A., and CARLINI-COTRIM, B. (1993). Illicit use of psychotropic drugs among brasilian students: 1987 and 1989 surveys. In Brasil - United States Binational Research, eds. M.G. Monteiro and J.A. Inciardi, 151-163. Sao Paulo, Brasil:CEBRID. 
CARLINI-COTRIM, B., and CARLINI, E. A. (1988). The use of solvents and other drugs among children and adolescents from a low socio economic background: A study in Sao Paulo, Brazil. International Journal of the Addictions 23:1145-1156.

DE PAULA, I. (1992). Drugs used by 100 percent of street children. Brasilia Correio Braziliense. 10(May):2.

DEWEES, A. and KLEES, S.J. (1995). Social movements and the transformation of national policy: Street and working children in Brazil. Comparative Education Review 39(1):76-100.

DIMENSTEIN, G. (1991). Brazil: War on children. London: Latin American Bureau.

DOS PASSOS, J. (1963). Brazil on the Move. New York: Paragon House.

EISENSTEIN, E. (1992). Street youth. Rio de Janeiro: Nucleo de estudos e pesquisas em atenção de drogas. Unpublished manuscript.

EISENSTEIN, E. (1993). Street youth: Social imbalance and health risks. Journal of Paediatrics and Child Health, supp. 1, 29:S46-S49.

EISENSTEIN, E. (1994). Access to health services specially [Sic] in relation to street children and drugs. Presented at Conference on Street Children and Psychoactive Substances, Geneva, Switzerland.

EISENSTEIN, E., and DE AQUINO, M. T. (1992). Street children and drugs. Rio de Janeiro: Nucleo de estudos e pesquisas em atenção de drogas. Unpublished manuscript.

ELLISON, K. (1994). Rio's tough street kids still live in fear. Miami Herald, July 28:12A

FACTS ON FILE. (1996). Officer convicted in massacre of youths. Facts on File, vol. 56, May 9:328-329.

FIREBAUGH, G. (1979). Structural determinants of urbanization in Asia and Latin America. American Sociological Review 44:199-215.

FREYRE, G. (1986). The Mansions and the Shanties. Berkeley: University of California Press.

GUILLERMOPRIETO, A. (1990). Samba. New York: Alfred A. Knopf.

GUNTHER, J. (1966). Inside South America. New York: Harper \& Row.

INTERNATIONAL CHILD RESOURCE INSTITUTE. (1994). Brazil Street Children Bulletin Summer:1-3.

INTERNATIONAL CHILD RESOURCE INSTITUTE. (1996). Brazil Street Children Bulletin Fall:1-2. 
JERI, F.R. (1984). Coca-paste smoking in some latin american countries: A severe and unabated form of addiction. Bulletin on Narcotics April-June:15-31.

JERI, F.R., SANCHEZ, C., and DEL POZO, T. (1976). Consumo de drogal peligrosas por miembros familiares de la fuerza armada y fuerza policial peruana. Revista de la Sanidad de las Fuerzas Policiales 37:104-112.

KIRSCH, H. [ed.] (1995). Drug Lessons and Education Programs in Developing Countries. New Brunswick, NJ:Transaction Publishers.

LARMER, B. (1992). Dead end kids. Newsweek, vol. 119, May 25:38-41.

Latinamerica Press (1996). "The three faces of Brazil," 28 (July 25): pp. 4-5).

LOVEMAN, B. (1991). Latin America faces public enemy No. 1. Institute of the Americas Hemisfile, vol. 2, July:6-8.

LUSK, M.W. (1989). Street children programs in Latin America. Journal of Sociology and Social Welfare 16:55-77.

MARTINS, J.P.S. (1992). Brazilian police go after street children. Latinamerica Press, April 16:7.

MARTINS, J.P.S. (1993). Children in Brazil victims through the ages. Latinamerica Press, December 23:4.

MICHAELS, M. (1993). Rio's dead end kids. Time, vol. 142, August 19:36-37.

PINTO, J. A., RUFF, A., PAIVA, J.V., ANTUNES, C.M., ADAMS, I., HALSEY, N., and GRECO, D. (1992). Comparative assessment of risk behavior and seroprevalence of HIV-1 among homeless and underprivileged youth in Belo Horizonte, Brazil. Presented at 8th International Conference on AIDS, Amsterdam, The Netherlands.

RAFFAELLI, M., MERRITT, P.,CAMPOS, R., SIQUEIRA, E., UDE, W., GRECO, M., GRECO, D., and HALSEY, N. (1992) Correlates of condom use among street youth in Belo Horizonte, Brazil. Presented at 8th International Conference on AIDS, Amsterdam, The Netherlands.

RAMBALI, P. (1993). In the Cities and Jungles of Brazil. New York:Henry Holt.

RAPHAEL, A., and BERKMAN, J. (1992). Children without a future. Brazil Network September:1-35.

RIZZINI, I. and LUSK, M.W. (1995). Children in the streets: Latin America's lost generation. Children and Youth Services Review 17(3):391-400.

SAUM, C.A., and INCIARDI, J.A. (1997). Rohypnol abuse in the United States. Substance Use and Misuse, in press. 
SCHEPER-HUGHES, N., and HOFFMAN, D. (1994). Kids out of place. NACLA Report on the Americas 27 (May/June):16-23.

SIQUEIRA, E., MERRITT, P., UDE, W., CAMPOS, R., GRECO, M., RAFFAELLI, M., HALSEY, N., and GRECO, D. (1992). HIV outreach communication intervention for brazilian street youth. Presented at 8th International Conference on AIDS, Amsterdam, The Netherlands.

THOMAS, J.J. (1995). Surviving the City: The Urban Informal Sector in Latin America. London:Pluto Press.

TILAK, J. (1989). Education and its relation to economic growth, poverty, and income distribution: Past evidence and further analysis. In World Bank Discussion Paper No.46. Washington, D.C.:World Bank.

UDE, W., PAYNE, A., ANTUNES, C., HOLT, E., RAFFAELLI, M., OTTONE, Z., ROLF, J., PINTO, J., PAIVA, J., CAMPOS, R., GRECO, M., SIQUEIRA, E., GRECO, D., RUFF, A., and HALSEY, N. (1991). A comparison of three methods of obtaining information from street youths regarding HIV risk behaviors. Presented at 7th International Conference on AIDS, Florence, Italy.

UNITED NATIONS CHILDREN'S FUND. (1996a). The State of the World's Children: 1996. Geneva:UNICEF.

UNITED NATIONS CHILDREN'S FUND. (1996b). Country Profile: Brazil. Geneva:UNICEF.

VAN BUUREN, N., and BEZERRA, C.A. (1992). The need to open a discussion about a public secret. Presented at 8th International Conference on AIDS, Amsterdam, The Netherlands.

VASCONCELOS, A. (1990). SOS Meninas. Recife, Brazil:Casa de Passagem.

WIIK, F.B., FILGUEIRAS, A., and CASTRO, M.L. (1989). Street teenagers and an AIDS prevention program in Brazil. Presented at 5th International Conference on AIDS, Montreal, Canada.

WOOD, C.H., and MANGO DE CARVALHO, J.A. (1988). The Demography of Inequality in Brazil. Cambridge: Cambridge University Press.

\section{About the Authors}

James A. Inciardi, Ph.D. is Director of the Center for Drug and Alcohol Studies at the University of Delaware; Professor in the Department of Sociology and Criminal Justice at Delaware; Adjunct Professor in the Department of Epidemiology and Public Health at the University of Miami School of Medicine; and a Distinguished Professor at the State University of Rio de Janeiro. Dr. Inciardi received his Ph.D. in sociology at New York University and has research, clinical, field, and teaching experience, in the areas of AIDS, substance abuse, and 
criminal justice. He has done extensive consulting work nationally and internationally and has published 40 books and more than 200 articles and chapters in the areas of substance abuse, criminology, criminal justice, history, folklore, social policy, AIDS, medicine, and law.

Hilary L. Surratt, M.A. is a Research Associate in the Comprehensive Drug Research Center at the University of Miami School of Medicine and is the Project Director of an HIV/AIDS seroprevalence and prevention study in Rio de Janeiro, Brazil. She also directs a female condom multi-site study. Both projects are funded by the National Institute on Drug Abuse. Ms. Surratt received her M.A. from the University of Florida, and has published in the areas of AIDS, substance abuse, and drug policy.

1. Because Brazilian currency tends to change and/or lose value rapidly, income is frequently calculated in terms of the number of minimum salaries earned, rather than a fixed monetary value. At the close of 1996 , the minimum wage per month was $\mathrm{R} \$ 100$, or $\$ 93.00$ in United States currency.

2. See Caracas (Venezuela) El Universal, 4 Oct. 1985, pp. 4, 30; Caracas Zeta, 12-23 Sept. 1985, pp. 39-46; Manaus (Brazil) Jornal Do Comercio, 20 May 1986, p. 16; Bogota El Tiempo, 1 June 1986, p. 3-A; Medellin El Colombiano, 22 July 1986, p. 16-A; Bogota El Tiempo, 6 Oct. 1986, p. 7-A; Lima (Peru) El Nacional, 14 Nov. 1986, p. 13; La Paz (Bolivia) Presencia, 3 March 1988, Sec. 2, p. 1; Sao Paulo (Brazil) Folha de Sao Paulo, 11 June 1987, p. A29; Buenos Aires (Argentina) La Prensa, 20 June 1987, p. 9; Sao Paulo O Estado de Sao Paulo, 8 March 1988, p. 18; Bogota El Espectador, 2 April 1988, pp. 1A, 10A; La Paz El Diario, 21 Oct. 1988, p. 3; Cochabamba (Bolivia) Los Tiempos, 13 June 1989, p. B5; Sao Paulo O Estado de Sao Paulo, 18 June 1989, p. 32; Rio de Janeiro (Brazil) Manchete, 28 Oct. 1989, pp. 20-29; Philadelphia Inquirer, 21 Sept. 1986, p. 25A; Timothy Ross, "Bolivian Paste Fuels Basuco Boom," WorldAIDS, Sept. 1989, p. 9.

3. Emmanuel's sentence of 309 years was largely symbolic, however, since the maximum legal sentence in Brazil is 30 years (Facts on File, 1996). 